\title{
Can Tc 99m DTPA be Used in Adult Patients in Evaluation of Relative Renal Function Measurement as the Reference Tc 99m DMSA Method?
}

\author{
Erişkin Hastalarda Rölatif Böbrek Fonksiyonlarının Hesaplanmasında \\ Tc 99m DTPA Referans Yöntem Tc 99m DMSA Gibi Kullanılabilir mi?
}

\author{
Hülya Yalı̧ın', Aynur Özen22, Emel Ceylan Günay 3, Inci Aliç Özaslan4, Cahit Özer5 \\ I Mustafa Kemal University School of Medicine, Department of Nuclear Medicine, Hatay, Turkey \\ 2Vakif Gureba Hospital, Department of Nuclear Medicine, Istanbul, Turkey \\ ${ }^{3}$ Mersin University School of Medicine, Department of Nuclear Medicine, Mersin, Turkey \\ ${ }^{4}$ Bagcilar Hospital, Department of Nuclear Medicine, Istanbul, Turkey \\ ${ }^{5}$ Mustafa Kemal University School of Medicine Department of Family Medicine, Hatay, Turkey
}

\begin{abstract}
Objective: In the literature, there are many reports comparing relative renal function calculated with Tc $99 \mathrm{~m}$ DTPA and Tc $99 \mathrm{~m}$ DMSA in adults and children. However, there is no consensus about the results. As there is indeterminacy in the reliability of Tc $99 \mathrm{~m}$ DTPA for the calculation of the relative renal functions, we retrospectively designed a study to compare the relative renal functions measured with Tc $99 \mathrm{~m}$ DMSA and Tc $99 \mathrm{~m}$ DTPA in adult patients with renal diseases

Material and Methods: We retrospectively analyzed the data of 144 patients who applied to Nuclear Medicine Department of three hospitals between 2009 and 2010 and who had both dynamic and static renal imaging. Renal dynamic scintigraphies were compared to the relative function measured using Tc $99 \mathrm{~m}$ DMSA static scintigraphy. Comparison of relative renal function measurements using dynamic and static renal scintigraphies was performed using Pearson correlation test. The comparison results were expressed with Bland-Altman analysis.

Results: The study was conducted with 144 patients and 288 kidneys. Fifty six of patients were male. Mean age was $39.9 \pm 15.2$ years. Thirty four patients had hydronephrosis, 28 pyelonephritis, 53 renal calculi, 3 chronic renal failure, 2 acute renal failure, 1 benign renal neoplasia, 15 renal atrophy, 8 ureteropelvic junction stenosis. Relative renal function was calculated in Tc 99m DMSA and 99m Tc-DTPA studies. The mean relative renal functions measured with Tc $99 \mathrm{~m}$ DTPA was $52.54 \pm 23.09 \%$ and $47.25 \pm 23.09$, with Tc $99 \mathrm{~m}$ DMSA $52.85 \pm 21.80 \%$ and $47.07 \pm 21.77 \%$ for right and left kidneys, respectively. In bivariate correlation analysis (Pearson) a significant positive correlation was found between the relative renal functions calculated with Tc 99m DTPA and Tc 99m DMSA ( $r=0.937, p<0.001)$. In Bland-Altman plots, the mean difference between two methods was 0.3 and the correlation limits were between 16.2 to -15.5 .

Conclusion: As a result, we concluded that Tc $99 \mathrm{~m}$ DTPA is also a good method for the relative renal function evaluation when compared to Tc $99 \mathrm{~m}$ DMSA scan. Although Tc $99 \mathrm{~m}$ DMSA is the most reliable method for the calculation of relative renal function, Tc $99 \mathrm{~m}$ DTPA can be another choice for the calculation of relative renal function without a complementary DMSA scan particularly in patients who require renogram curve and GFR calculations. (MIRT 2011; 20:14-8)

Key words: Relative renal function, Tc $99 \mathrm{~m}$ DTPA, Tc $99 \mathrm{~m}$ DMSA, adults
\end{abstract}

Address for Correspondence: Hülya Yalçın, MD, Mustafa Kemal University School of Medicine, Department of Nuclear Medicine, 31100 Antakya, Hatay, Turkey Fax: +90 3262144977 E-mail: hulyapeker@yahoo.com Received: 18.08.2010 Accepted: 23.02.2011

Molecular Imaging and Radionuclide Therapy, published by Galenos Publishing 


\section{Özet}

Amaç: Literatürde, erișkin ve çocuklarda Tc 99m DTPA ve Tc 99m DMSA ile hesaplanan rölatif böbrek fonksiyonları ile ilgili birçok yayın bulunmaktadır. Ancak, sonuçlar birbirleri ile çelișmektedir. Bu nedenle, retrospektif olarak erişkin böbrek hastalarında Tc 99m DMSA ve Tc 99m DTPA ile hesaplanan rölatif böbrek fonksiyonlarını karșılaștırılması amacı ile bu çalıșma planlandı.

Gereç ve Yöntemler: Çalıșmamızda 2009-2010 yılları arasında Tc 99m DTPA ile dinamik ve Tc 99m DMSA ile statik böbrek sintigrafisi için üç hastanede nükleer tıp bölümüne başvurmus 144 hasta geriye dönük olarak incelendi. Dinamik ve statik böbrek sintigrafileri ile hesaplanan rölatif böbrek fonksiyonları Pearson korelasyon testi ve Bland-Altman analizi kullanılarak karșilaștırıldı.

Bulgular: Hastalarımızın elli altısı erkekti. Yașları 18 ile 81 arasında değișmekte olup, ortalama yas $39.9 \pm 15.2$ yıl olarak hesaplandı. Otuz dört hastada hidronefroz, 82 hastada piyelonefrit, 53 hastada tas, 3 hastada kronik böbrek yetmezliği, 2 hastada akut böbrek yetmezliği, 1 hastada benign böbrek neoplazmı, 15 hastada atrofi, 8 hastada üreteropelvik bileșke darlığı vardı. Tc 99m DMSA ve Tc 99m DTPA ile rölatif böbrek fonksiyonları hesaplandı. 99m Tc-DTPA ile ölçülen ortalama rölatif böbrek fonksiyonu sağ böbrek için \%52.54 23.09 ve sol için

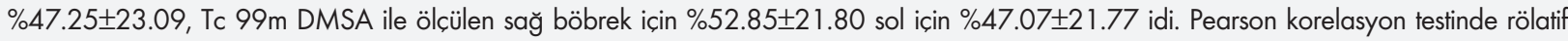
böbrek fonksiyonlarının hesaplanmasında Tc 99m DTPA ve Tc 99m DMSA arasında pozitif korelasyon bulundu $(r=0.937, p<0.001)$. BlandAlıman analizinde, iki yöntem arasında ortalama fark 0.3 bulunmus olup, uyum limitleri 16.2 ile -15.5 arasındaydı.

Sonuç: Sonuç olarak, Tc 99m DMSA rölatif böbrek fonksiyonlarının hesaplanmasında en güvenilir yöntem olmasına rağmen, Tc 99m DTPA da özellikle glomerüler filtrasyon hızı ve renogram grafiklerinin de gerektiği erișkin hasta grubunda rölatif böbrek fonksiyon hesabı için iyi bir yöntemdir. (MIRT 2011; 20: 14-8)

Anahtar kelimeler: Rölatif böbrek fonksiyonu, Tc 99m DTPA, Tc 99m DMSA, erișkin

\section{Introduction}

To measure the relative renal function, renal scintigraphy has been used for a long time. Different radiopharmaceuticals such as technetium-99m dimercaptosuccinic acid (Tc 99m DMSA), technetium- $99 \mathrm{~m}$ diethylenetriamine pentaacetic acid (Tc 99m DTPA), technetium-99m mercaptoacetyltriglycine (Tc 99m MAG3), iodine 131 orthoiodohippurate $(\mathrm{OIH})$ and more recently technetium-99m ethylenedicysteine (Tc 99m EC) were used (1). All of them can be used accurately to measure the relative renal function, although there are some differences among these radiopharmaceuticals (2) These differences are due to distinct biological properties of radiopharmaceuticals such as mechanisms of renal excretion, renal cell retention of radioactive material, level of plasma-protein bound and level of plasma clearance. However, Tc $99 \mathrm{~m}$ DMSA as a static renal agent is considered the most reliable method to measure relative renal function $(3,4,5)$ and the most appropriate tracer for renal cortical imaging (6). Tc $99 \mathrm{~m}$ DMSA binding level to protein in mammals is $90 \%$, this binding prevents significant glomerular filtration and Tc $99 \mathrm{~m}$ DMSA primarily enters the kidney via peritubular extraction (7). It is primarily used in humans for cortical imaging and estimation of functional renal mass $(8,9,10)$. Applications in humans include detection of pyelonephritis (1 1 ) and renal scars $(12,13)$. Tc 99m DTPA is used for glomerular filtration rate (GFR) evaluation in mammals because no tubular secretion or reabsorption is observed but it is completely filtered by the glomerulus $(8,10,14)$ In the literature, there are many reports comparing relative renal function calculated with Tc 99m DTPA and Tc 99m DMSA in adults and children. However, there is no consensus about the results and no study investigating the relative renal function calculation only in adults. In some papers, it is emphasized that relative renal function calculated with Tc $99 \mathrm{~m}$ DTPA is as reliable as Tc $99 \mathrm{~m}$ DMSA $(15,16)$. On the other hand, in some of the studies, it is mentioned that Tc $99 \mathrm{~m}$ DTPA is not as good as Tc $99 \mathrm{~m}$ DMSA in relative renal function calculation $(17,18)$ As there is indeterminacy in the reliability of Tc $99 \mathrm{~m}$ DTPA for the calculation of relative renal function and lack of any study related to relative renal function calculation only in adults; we retrospectively designed a study to compare the relative renal functions measured with Tc $99 \mathrm{~m}$ DMSA and Tc $99 \mathrm{~m}$ DTPA in adult patients with renal diseases.

\section{Materials and Methods}

We retrospectively analyzed a total of 144 patients who applied to the Nuclear Medicine Department of three hospitals between 2009-2010 and who had both dynamic and static renal imaging. Renal dynamic scintigraphies performed with Tc $99 \mathrm{~m}$ DTPA were compared to the relative function measured using Tc 99m DMSA static scintigraphy. There was at least 2 days between two studies and not more than a week. The data analyses were done in each hospital by a nuclear medicine physician.

Tc 99m DTPA dynamic images were acquired with the patient in supine position and the detector of gamma camera placed at the posterior. The cameras [Symbia S (Siemens, Germany), E-cam (Siemens, USA), Brightview (Philips,USA)] were equipped with an all-purpose, low energy, parallel-hole collimator. All patients were injected with 259-370 MBq of Tc $99 \mathrm{~m}$ DTPA, and dynamic images were recorded in a $128 \mathrm{x}$ 128 matrix format every second for 1 minute and every 30 seconds for 20 minutes. Relative renal function was measured in a composite image ( 1 to 3 minutes after the injection). Renal 
and semilunar background regions of interest (ROIs) were drawn manually by a nuclear medicine physician. Tc $99 \mathrm{~m}$ DMSA static images were also acquired with the patient in supine position. The camera was also equipped with an all-purpose, low energy, parallel-hole collimator. All patients were injected with $185 \mathrm{MBq}$ of the radiopharmaceutical and static images were acquired in $256 \times 256$ matrix after 4 hours in the anterior, posterior, left and right posterior oblique, left and right lateral projections (250 kcounts/view or 5 minutes/view). Relative renal function was measured by drawing ROls of each kidney in the anterior and posterior image with background correction made by drawing a perirenal background around each kidney by a nuclear medicine physician and relative renal function was calculated using the geometric mean method.

Comparison of relative renal function measurement using Tc 99m DTPA dynamic renal scintigraphy and Tc 99m DMSA static scintigraphy was performed by Pearson correlation and Kruskal Wallis test. The comparison results were expressed with
Bland-Altman analysis. The statistical analysis was carried out using the Statistical Package for the Social Sciences (SPSS) version 15 (SPSS, Chicago, IL).

\section{Results}

The study was conducted with 144 patients from three hospitals retrospectively. The hospital charts of 144 patients were reviewed and the results of 288 kidneys were analyzed. Fifty six of patients were male and eighty eight female. The age range was between 18 and 81 , mean age was $39.9 \pm 15.2$ years. Thirty four patients had hydronephrosis, 28 pyelonephritis, 53 renal calculi, 3 chronic renal failure, 2 acute renal failure, 1 benign renal neoplasia, 15 renal atrophy, 8 ureteropelvic junction stenosis.

Relative renal function measured with Tc $99 \mathrm{~m}$ DMSA and $99 \mathrm{~m}$ Tc-DTPA was calculated. The mean relative renal functions measured with Tc $99 \mathrm{~m}$ DTPA was $52.54 \pm 23.09 \%$ and

Table 1. The mean, maximum and minimum (\%) values of relative renal function calculated for each

\begin{tabular}{|c|c|c|c|c|c|}
\hline & & Right kidney DMSA & Left kidney DMSA & Right kidney DTPA & Left kidney DTPA \\
\hline \multirow[t]{4}{*}{ Hidronephrosis } & Mean (\%) & 48.165 & 51.835 & 47.688 & 52.312 \\
\hline & Std. Deviation & 15.5123 & 15.4998 & 17.7224 & 17.7224 \\
\hline & Minimum (\%) & .1 & 21.0 & .5 & 11.0 \\
\hline & Maximum (\%) & 79.0 & 99.9 & 89.0 & 99.5 \\
\hline \multirow[t]{4}{*}{ Pyelonephritis } & Mean (\%) & 55.961 & 44.039 & 55.746 & 44.254 \\
\hline & Std. Deviation & 20.4117 & 20.4117 & 21.0827 & 21.0827 \\
\hline & Minimum (\%) & 7.0 & 6.0 & 9.0 & 5.0 \\
\hline & Maximum (\%) & 94.0 & 93.0 & 95.0 & 91.0 \\
\hline \multirow[t]{4}{*}{ Calculi } & Mean (\%) & 54.079 & 45.732 & 54.681 & 45.319 \\
\hline & Std. Deviation & 22.6557 & 22.5607 & 23.2231 & 23.2231 \\
\hline & Minimum (\%) & 5.0 & 4.0 & 6.0 & 6.0 \\
\hline & Maximum (\%) & 96.0 & 95.0 & 94.0 & 94.0 \\
\hline \multirow[t]{4}{*}{ Renal failure } & Mean (\%) & 33.940 & 66.060 & 30.920 & 69.080 \\
\hline & Std. Deviation & 20.3573 & 20.3573 & 20.2961 & 20.2961 \\
\hline & Minimum (\%) & 5.0 & 49.0 & 5.0 & 49.0 \\
\hline & Maximum (\%) & 51.0 & 95.0 & 51.0 & 95.0 \\
\hline \multirow[t]{5}{*}{ Renal atrophy } & Mean (\%) & 56.820 & 43.180 & 54.613 & 45.387 \\
\hline & Std. Deviation & 33.6433 & 33.6433 & 36.7114 & 36.7114 \\
\hline & Median (\%) & 57.900 & 42.100 & 43.200 & 56.800 \\
\hline & Minimum (\%) & 5.0 & 7.6 & .0 & 1.3 \\
\hline & Maximum (\%) & 92.4 & 95.0 & 98.7 & 100.0 \\
\hline \multirow{4}{*}{$\begin{array}{l}\text { Ureteropelvic } \\
\text { junction stenosis }\end{array}$} & Mean (\%) & 59.013 & 40.988 & 58.275 & 41.725 \\
\hline & Std. Deviation & 12.7841 & 12.7841 & 13.5932 & 13.5932 \\
\hline & Minimum (\%) & 48.0 & 16.7 & 46.0 & 19.6 \\
\hline & Maximum (\%) & 83.3 & 52.0 & 80.4 & 54.0 \\
\hline \multirow[t]{4}{*}{ Total } & Mean (\%) & 52.853 & 47.078 & 52.544 & 47.456 \\
\hline & Std. Deviation & 21.8067 & 21.7729 & 23.0927 & 23.0927 \\
\hline & Minimum (\%) & .1 & 4.0 & .0 & 1.3 \\
\hline & Maximum (\%) & 96.0 & 99.9 & 98.7 & 100.0 \\
\hline$p$ & & 0.132 & 0.117 & 0.212 & 0.212 \\
\hline
\end{tabular}




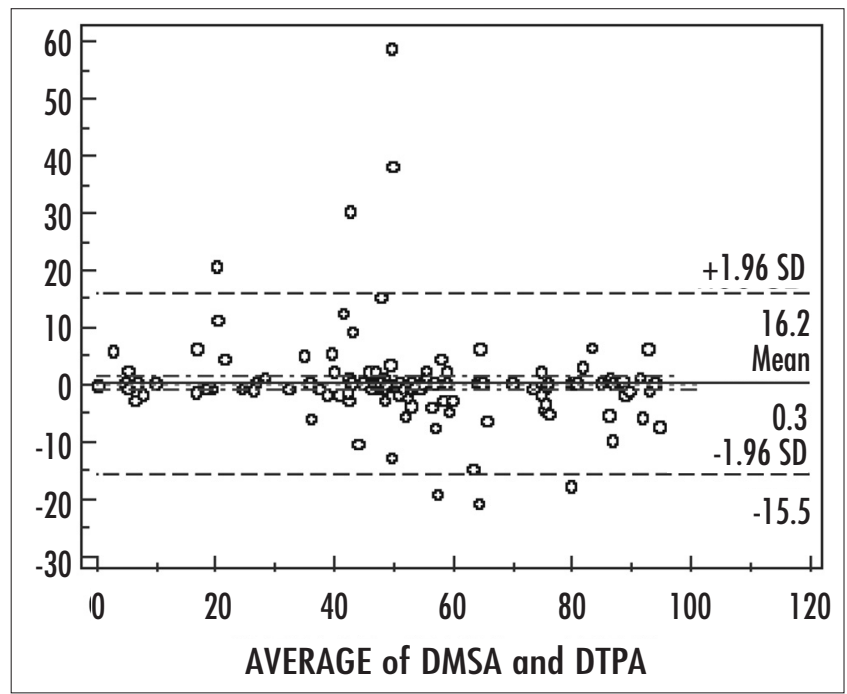

Figure 1. Bland-Altman analysis between Tc 99m DMSA and Tc 99m DTPA

$47.25 \pm 23.09 \%$, with Tc $99 \mathrm{~m}$ DMSA $52.85 \pm 21.80 \%$ and $47.07 \pm 21.77 \%$ for right and left kidneys, respectively. In bivariate correlation analysis (Pearson) a significant positive correlation was found between the relative renal functions calculated with Tc 99m DTPA and Tc 99m DMSA ( $r=0.937, p<0.001)$. When the data were analyzed with Kruskal Wallis test according the patients diagnosis, we did not find differences between relative renal function calculated with both imaging methods $(p=0.132$ for right and $p=0.17$ left kidney with Tc 99m DMSA, $p=0.212$ for both kidneys with Tc $99 \mathrm{~m}$ DTPA) (Table 1). In Bland-Altman plots, the mean difference between two methods was 0.3 and the correlation limits were between 16.2 to -15.5 . Some values were out of the range; these were mostly related to kidneys with lower split renal function in Tc 99m DMSA (Figure 1).

\section{Discussion}

As we mentioned before, there are many reports comparing the relative renal function calculation results of Tc $99 \mathrm{~m}$ DTPA and Tc $99 \mathrm{~m}$ DMSA. However in our literature search we could not find any reports comparing the results of the relative renal function measured with Tc 99m DTPA and Tc $99 \mathrm{~m}$ DMSA in a group of adult patients only with various renal diseases. The previous studies were performed in group of patients including adult and pediatric patients.

Taylor and his co-workers investigated the correlation between the relative renal uptake of Tc 99m DMSA and the relative glomerular filtration rate (GFR) in ten patients with serum creatinine ranging from 0.3 to $2.5 \mathrm{mg} / \mathrm{dl}$. They used two methods to determine the renal uptake of Tc $99 \mathrm{~m}$ DTPA. These methods showed excellent correlation with each other and with relative DMSA uptake (19).

In 2001, Sarı and Serdengeçti compared relative renal functions obtained with Tc $99 \mathrm{~m}$ DTPA and Tc 99m DMSA in 42 patients. Their study group consisted mainly of children with a mean age of 10,5 years. They concluded that there were no statistical differences between relative renal function calculated with Tc 99m DTPA and Tc 99m DMSA. However, Tc $99 \mathrm{~m}$ DMSA, as it is less expensive and easy to perform, could be an appropriate method to calculate relative renal function (15).

On the other hand, in 2006, Domingues and his co-workers performed a study with 111 patients with age ranging between 0.17 to 79 years. Fifty five of patients had dynamic renal scintigraphy with Tc $99 \mathrm{~m}$ DTPA and 56 with Tc $99 \mathrm{~m}$ EC. All patients were imaged with Tc $99 \mathrm{~m}$ DMSA. The relative renal functions calculated with Tc $99 \mathrm{~m}$ DTPA and Tc $99 \mathrm{~m}$ EC was compared with the results of Tc $99 \mathrm{~m}$ DMSA. They concluded that relative renal function measured with Tc $99 \mathrm{~m}$ EC was comparable to Tc $99 \mathrm{~m}$ DMSA results, but the results of relative renal function measured with Tc 99m DTPA were statistically different (17).

In 2010, Lee and his colleagues calculated the relative renal function in 18 rabbits with unilateral ureteral obstruction. All the rabbits were imaged with Tc $99 \mathrm{~m}$ DMSA or Tc $99 \mathrm{~m}$ DTPA or Tc $99 \mathrm{~m}$ MAG-3. The relative renal function was calculated and they found that although there were differences between left and right kidneys, no statistical differences were observed between groups. So, they concluded that dynamic renal imaging agents (Tc 99m DTPA and Tc $99 \mathrm{~m}$ MAG-3) can be used to measure the relative renal function in place of the static image of Tc 99m DMSA (16).

In our study, we compared relative renal functions obtained with Tc 99m DTPA and Tc 99m DMSA in 144 adult patients (288 kidneys). The mean age was $39.9 \pm 15.2$ years. We found a positive correlation between relative renal function calculated with Tc 99m DTPA and Tc 99m DMSA $(r=0.937, p<0.001)$. Our study group consisted mostly of patients with diseases in which GRF and renogram curves are were as important as relative renal function.

Even Tc $99 \mathrm{~m}$ DMSA is an inexpensive and easy method20 used for cortical morphology and renal scar evaluation, patients who need the GFR and renogram curve results, the relative renal function calculated with Tc $99 \mathrm{~m}$ DTPA may be used instead of static renal imaging with Tc $99 \mathrm{~m}$ DMSA, since the comparison of the relative renal function results of Tc $99 \mathrm{~m}$ DMSA and Tc $99 \mathrm{~m}$ DTPA shows no statistical difference. There were some values out of range in Bland-Altman plots. These kidneys were mostly atrophic or hydronephrotic kidneys. In correlation to literature results, we thought that the difference between two methods was related to depth and location of the renal tissue $(21,22)$.

\section{Study Limitations}

In multicenter studies, reproducibility analysis should be performed. In other words, the differences of relative renal function calculations with Tc $99 \mathrm{~m}$ DMSA may have variability in different centers. However, in human studies this kind of analysis is practically difficult and ethically problematic. Because of the reasons mentioned above, we were not able to make a definition of reproducibility analysis in the current study. 
As a result, we concluded that Tc $99 \mathrm{~m}$ DTPA is also a good method for the relative renal function evaluation when compared to Tc $99 \mathrm{~m}$ DMSA scan. Although Tc $99 \mathrm{~m}$ DMSA is the most reliable method for the calculation of relative renal function, Tc 99m DTPA can be another choice for the calculation of relative renal function without a complementary DMSA scan particularly in patients who require renogram curve and GFR calculations.

\section{References}

1. Moran JK. Technetium-99m-EC and other potential new agents in renal nuclear medicine. Semin Nucl Med 1999;29:91-101.

2. Taylor A Jr, Lallone R. Differential renal function in unilateral renal injury: possible effects of radiopharmaceutical choice. J Nucl Med 1985;26:77-80

3. Ardela Diaz E, Miguel Martinez B, Gutierrez Duenas JM, Diez Pascual R, Garcia Arcal D, Dominguez Vallejo FJ. Comparative study of differential renal function by DMSA and MAG-3 in congenital unilateral uropathies. Cir Pediatr 2002;15:118-121.

4. Kawashima A, Sandler CM, Goldman SM. Current roles and controversies in the imaging evaluation of acute renal infection. World J Urol 1998;16:9-17.

5. Piepsz A. Cortical scintigraphy and urinary tract infection in children. Nephrol Dial Transplant 2002; 17:560-562.

6. Piepsz A, Blaufox MD, Gordon I, Granerus G, Majd M, O'Reilly P, Rosenberg AR, Rossleigh MA, Sixt R. Consensus on renal cortical scintigraphy in children with urinary tract infection. Scientific Committee of Radionuclides in Nephrourology. Semin Nucl Med 1999;29:160-174.

7. Verbruggen $A M$, Nosco DL, Van Nerom CG, Bormans GM, Adriaens PJ, De Roo MJ. Technetium-99m-L, L-ethylenedicysteine: a renal imaging agent. I. Labeling and evaluation in animals. J Nucl Med 1992;33:551-557.

8. Daniel GB,Mitchell SK, Mawby D, Sackman JE, Schmidt D. Renal nuclear medicine: a review. Vet Radiol Ultrasound 1999;40:572-587.

9. Muller-Suur R, Gutsche HU. Tubular reabsorption of technetium-99mDMSA. J Nucl Med 1995;36:1654-1658.

10. Campbell MG, Powers TA. Renal radionuclides and in vitro quantitation. In: Sandler MP, Coleman RE, Patton JA, Wackers FJT, Gottschalk A eds. Diagnostic nuclear medicine, 4th ed. Philadelphia: Lippincott Williams \& Wilkins; 2003;851-64.
11. Majd M, Rushton HG. Renal cortical scintigraphy in the diagnosis of acute pyelonephritis. Semin Nucl Med 1992;22:98-111.

12. Hitzel A, Liard A, Dacher JN, Gardin I, Ménard JF, Manrique A, Véra P. Quantitative analysis of Tc $99 \mathrm{~m}$ DMSA during acute pyelonephritis for prediction of long-term renal scarring. J Nucl Med 2004;45:285-289.

13. Shanon A, Feldman W, McDonald P, Martin DJ, Matzinger MA, Shillinger JF, McLaine PN, Wolfish N. Evaluation of renal scars by technetium-labeled dimercaptosuccinic acid scan, intravenous urography, and ultrasonography: a comparative study. J Pediatr 1992; 1 20:399-403.

14. Urhan M, Mavi A, Sağer MS, Kınalp RC, Narin Y. A Comparison of Glomerular Filtration Rate Measurement Methods Using Technetium-99m Diethylenetriaminepentaacetic Acid, Turk J Nucl Med 2007;16:25-31.

15. Sarı O, Serdengeçti M. Tc $99 \mathrm{~m}$ DMSA ve Tc $99 \mathrm{~m}$ DTPA ile hesaplanan rölatif böbrek fonksiyonlarının karșılaștııııması. Genel Tıp Dergisi 2001;11:149-151.

16. Lee WG, Kim JH, Kim JM, Shim KM, Kang SS, Chae HI, Choi SH. Renal uptakes of Tc $99 \mathrm{~m}$ MAG3, Tc $99 \mathrm{~m}$ DTPA, and Tc $99 \mathrm{~m}$ DMSA in rabbits with unilateral ureteral obstruction. In Vivo 2010;24:137-139.

17. Domingues FC, Fujikawa GY, Decker H, Alonso G, Pereira JC, Duarte PSnt Braz J Urol. Comparison of relative renal function measured with either Tc 99m DTPA or Tc $99 \mathrm{~m}$ EC dynamic scintigraphies with that measured with Tc $99 \mathrm{~m}$ DMSA static scintigraphy 2006;32:405-409.

18. Sedlak-Vadoc V, Basiç M, Kaludjerski S, Marusiç G, Negrojeviç M, Borota R.The effect of radiopharmaceutical choice on the assessment of the relative renal function in upper urinary tract obstruction. Eur J Nucl Med 1988;14:32-36.

19. Taylor A Jr, Kipper M, Witztum K. Calculation of relative glomerular filtration rate and correlation with delayed technetium-99m DMSA imaging. Clin Nucl Med 1986;1 1:28-31.

20. Nimmo MJ, Merrick MV, Allan PL. Measurement of relative renal function. A comparison of methods and assessment of reproducibility. Br J Radiol 1987;60:861-864.

21. Yapar AF, Aydin M, Reyhan M, Yapar Z, Sukan A. The conditions for which the geometric mean method revealed a more accurate calculation of relative renal function in Tc $99 \mathrm{~m}$ DMSA scintigraphy. Nucl Med Commun. 2005;26:141-146.

22. Hervás I, Martí JF, González A, Ruiz JC, Alonso J, Bello P, Manzano F, Torres I, Mateo A. Is the depth correction using the geometric mean really necessary in a $99 \mathrm{Tcm}-\mathrm{DMSA}$ scan in the paediatric population? Nucl Med Commun 2001;22:547-552. 